\title{
Bentuk Analogi Seni Pertunjukan dalam Arsitektur
}

\author{
Laksmi Dewayani dan Nur Endah Nuffida \\ Departemen Arsitektur, Fakultas Teknik Sipil dan Perencanaan, Institut Teknologi Sepuluh Nopember (ITS) \\ e-mail:nuffida@gmail.com
}

\begin{abstract}
Abstrak-Indonesia memiliki keragaman budaya. Keragaman budaya tersebut sudah dikenal hingga mancanegara. Keragaman yang ada di Indonesia terdiri atas bahasa, perilaku, cara berpakaian, makanan, kesenian, dan lain-lain. Kesenian adalah bagian dari kebudayaan, dimana merupakan sarana untuk mengekspresikan rasa jiwa manusia yang memiliki unsur keindahan dan keelokan, dimana proses penciptaannya dapat melengkapi sisi batin bagi manusia (emosional). Kesenian terdiri atas seni tari, seni musik, seni rupa, seni kontemporer, serta seni peran. Pada proyek pernacangan ini, metafora yang penulis gunakan ada combined metaphor, dimana pada bentuk, konsep dalam serta plaza dapat mengadaptasi dari unsur pertunjukan. Dengan proses pendekatan movement, modern, dan image pada metode metafora, sehingga keluaran objek arsitektural mengarah kepada bentukan baik secara visual maupun tidak. Dengan menjadikan arsitektur sebagai bentuk dari bahasa maka akan dapat memberikan kemudahan bagi metafora untuk berkomunikasi langsung dengan arsitektur salah satu contoh memetaforakan bentuk-bentuk arsitektur seperti konsep, analisa dan sebagainya.
\end{abstract}

Kata Kunci-Analogi, Image, Movement, Modern.

\section{PENDAHULUAN}

$\mathrm{K}$ EBUDAYAAN merupakan salah satu ciri khas dari Indonesia yang sudah dikenal hingga mancanegara. Beragamnya kebudayaan inilah yang mendorong masyarakat Indonesia sendiri untuk mengetahui ataupun mempelajarinya. Hal tersebut tidak menutup kemungkinan bahwa masyarakat Indonesia juga belajar budaya asing seiring dengan era globalisasi, keragaman serta keindahan yang ada dari budaya luar mulai banyak diadaptasi dan dikreasikan dengan budaya asli Indonesia itu sendiri.

Kesenian adalah bagian dari kebudayaan, dimana merupakan sarana untuk mengekspresikan rasa jiwa manusia yang memiliki unsur keindahan dan keelokan, dimana proses penciptaannya dapat melengkapi sisi batin bagi manusia (emosional). Kesenian terdiri atas seni tari, seni musik, seni rupa, seni kontemporer, serta seni peran (seperti wayang dan cerita Ramayana-Shinta).

Pertunjukan, salah satu upaya untuk merepresentasikan hasil karya seseorang ataupun kelompok dalam bidang seni. Pertunjukan-pertunjukan yang biasa penulis kunjungi (menurut pengalaman pribadi penulis) sudah semakin berkembang, dari acara-acara musikal, sentratari baik domestik maupun internasional, meliputi bidang pertunjukan tarian klasik, tari tradisional, tari modern, tari kontemporer, dan sebagainya. Dengan masuknya budaya-budaya internasional inilah yang juga memicu peminat seni di Indonesia semakin berkembang pula.

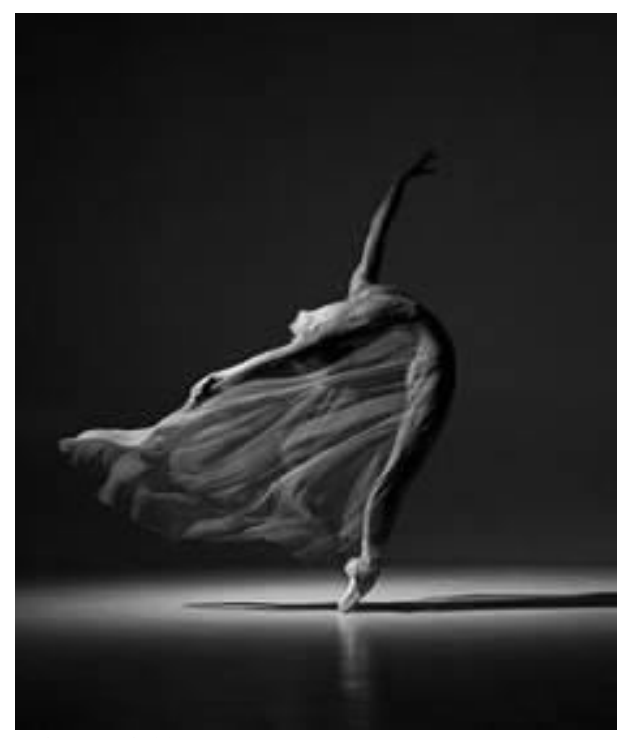

Gambar 1. Seni pertunjukkan.

Sumber: Google

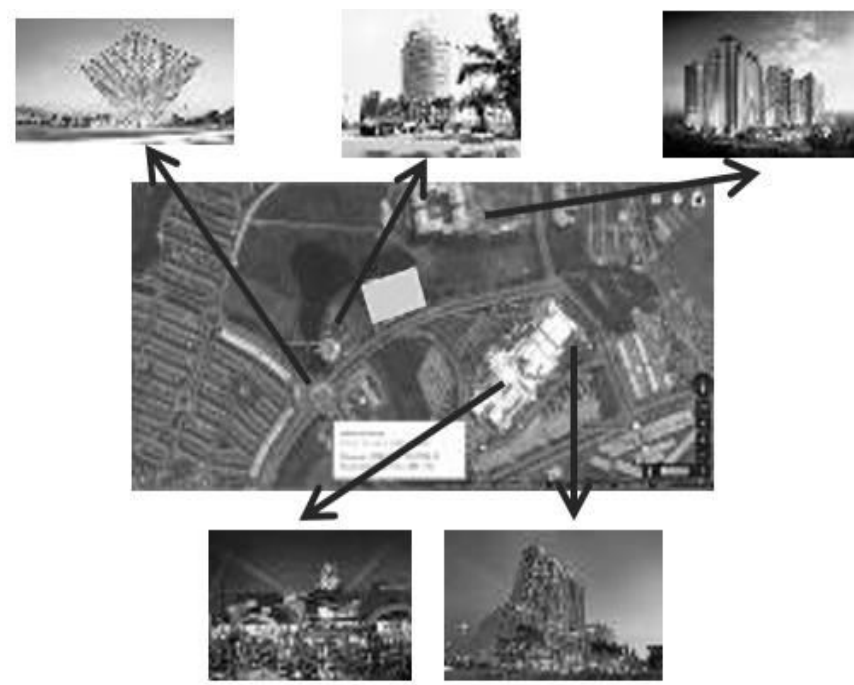

Gambar 2. Batasan Lahan Eksisting.

Sumber: Google

Gedung Pertunjukkan sebagai wadah pembuktian adanya bentuk arsitektur bagi pengguna objek rancangan untuk mendalami karakteristik / kualitas objek dalam edukasi khususnya bidang seni pertunjukan, menunjukkan identitas budaya bagi suatu daerah tertentu, serta dapat membangun ruang baru yang dapat digunakan pada fungsi kegiatan yang berbeda-beda. 


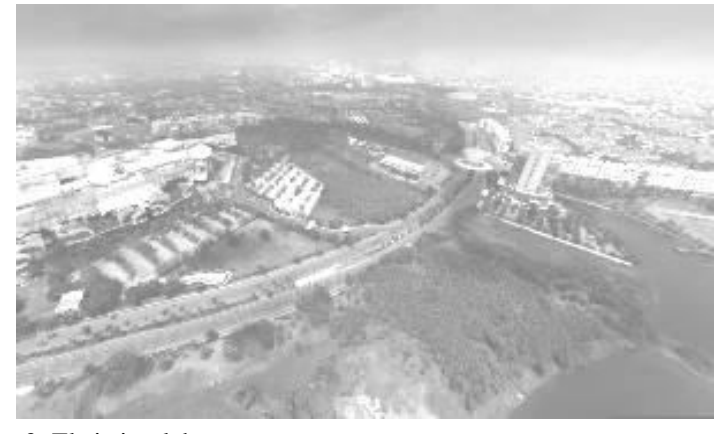

Gambar 3. Eksisting lahan.

Sumber: Google Maps

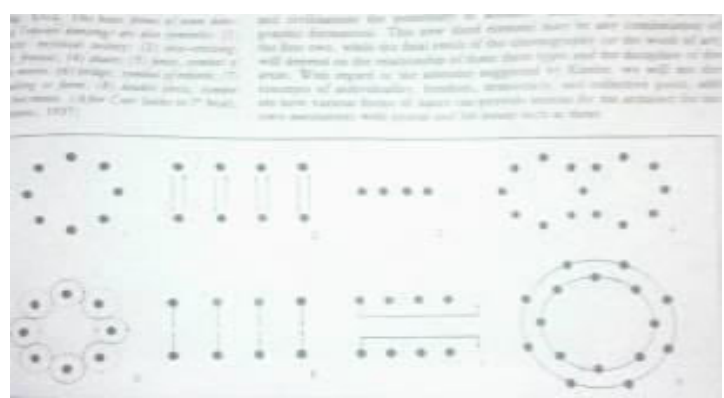

Gambar 4. Bentukan dasar dari tarian grup (tim) dari Frederick Kiesler. Sumber: Poetics of Architecture

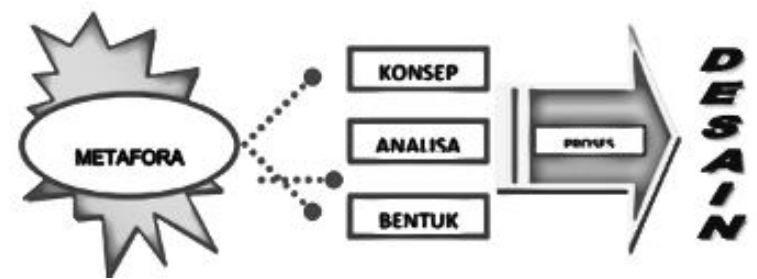

Gambar 5. Proses Pemikiran metode metafora. Sumber: Google

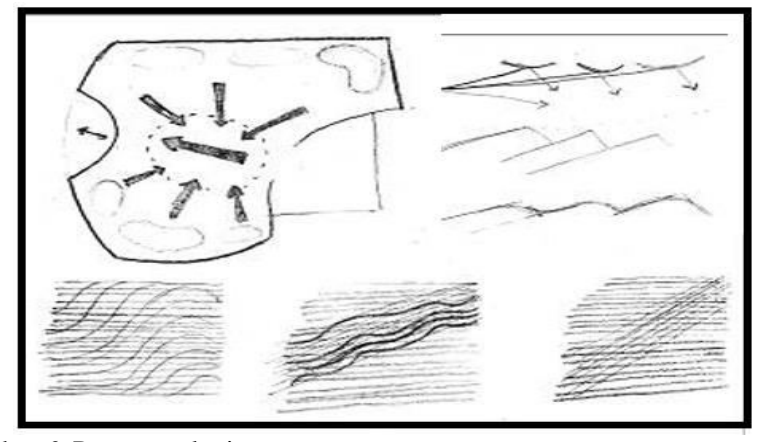

Gambar 6. Proses analogi.

Sumber: Dokumentasi Pribadi

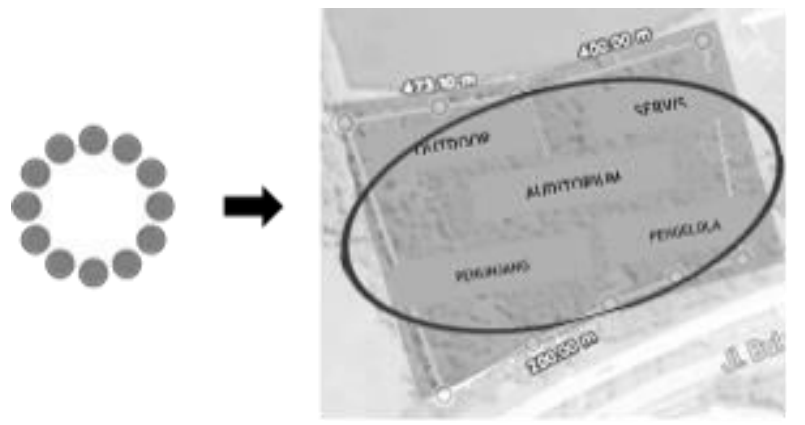

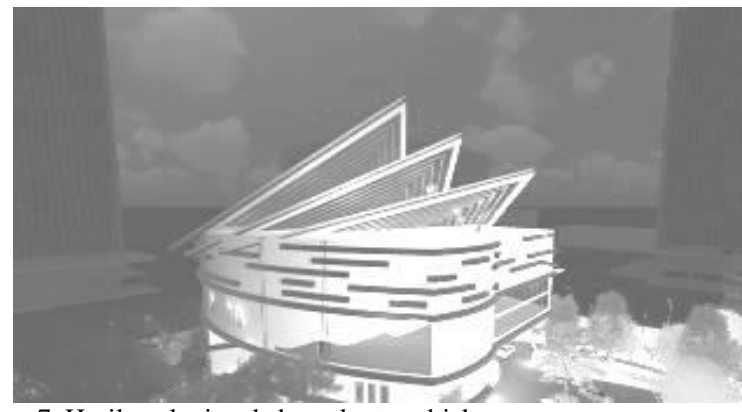

Gambar 7. Hasil analogi pada bentuk atap objek rancang.

Sumber: Dokumentasi Pribadi

Gambar 8. Pola penerapan unsur society.

Sumber: Dokumentasi Pribadi

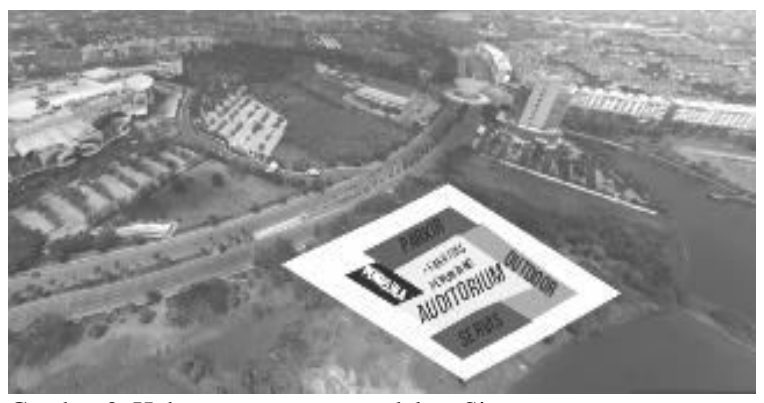

Gambar 9. Hubungan antar ruang dalam Site.

Sumber: Dokumentasi Pribadi

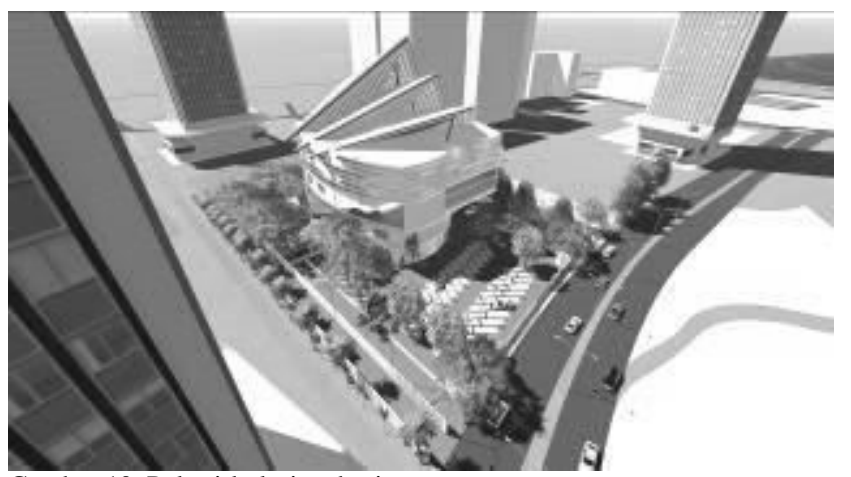

Gambar 10. Pola sirkulasi pada site.

Sumber: Dokumentasi Pribadi

\section{II.METODE PERANCANGAN}

Metafora merupakan suatu metode yang memandang suatu bangunan atau konsepsebagai sesuatu yang berbeda. Menurut Anthony C. Antoniades dalam bukunya Poetics of Architecture: Theory of Design, metafora dapat dikelompokkan menjadi 3: Intangible Metaphor (Metafora tak teraba), Tangible Metaphor (Metafora teraba), dan Combined Metaphor (Metafora kombinasi) (gambar 5).

Pada proyek pernacangan ini, metafora yang penulis gunakan ada combined metaphor, dimana pada bentuk, konsep dalam serta plaza dapat mengadaptasi dari unsur pertunjukan. Dengan menjadikan arsitektur sebagai bentuk dari bahasa maka akan dapat memberikan kemudahan bagi metafora untuk berkomunikasi langsung dengan arsitektur salah satu contoh memetaforakan bentuk-bentuk arsitektur seperti konsep, analisa dan sebagainya. 

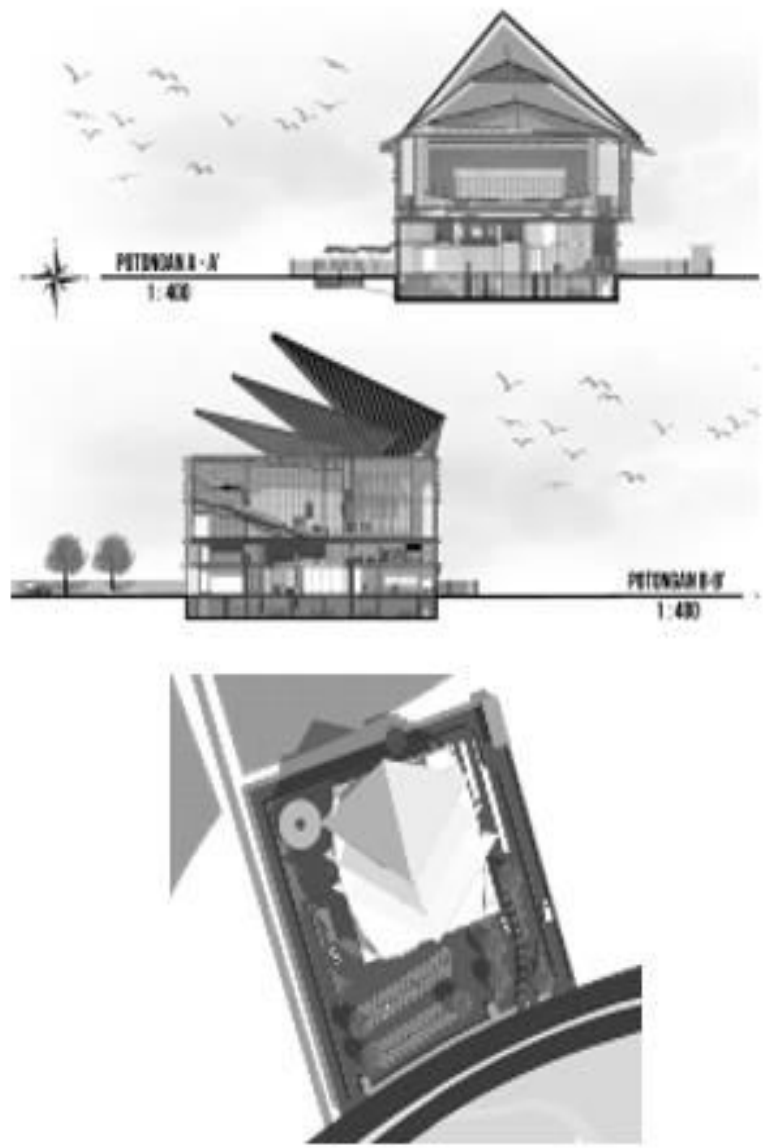

Gambar 11. Orientasi Massa Bangunan

Sumber: Dokumentasi Pribadi
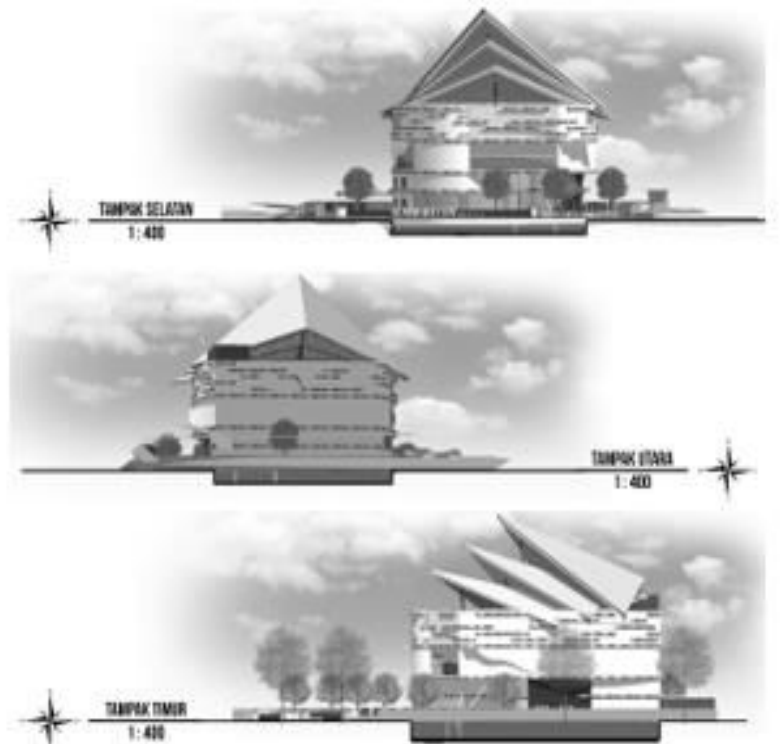

Gambar 12. Tampak Bangunan

Sumber: Dokumentasi Pribadi

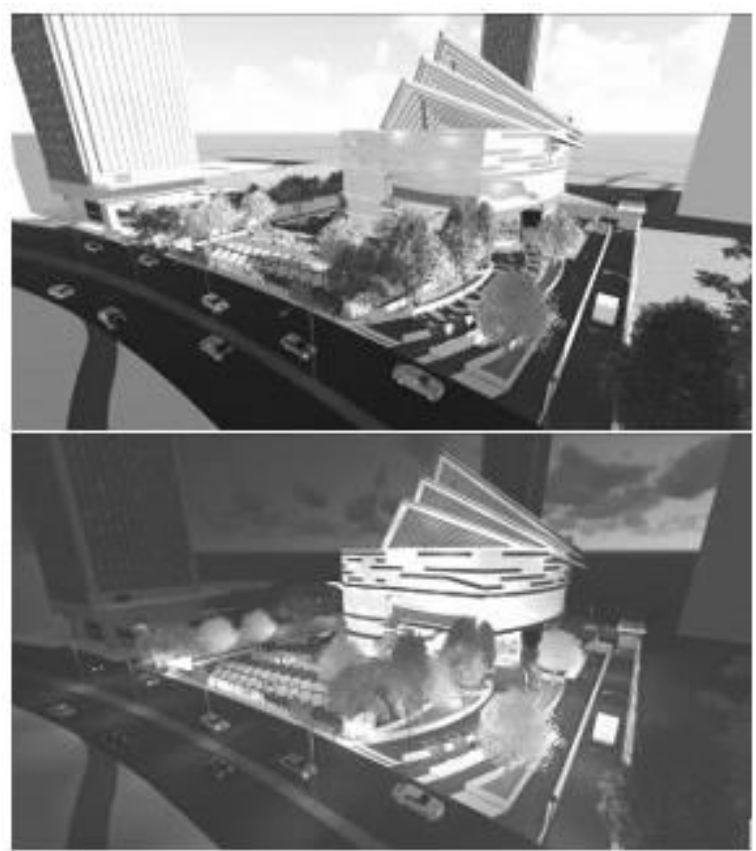

Gambar 13. Tampak Bangunan

Sumber: Dokumentasi Pribadi

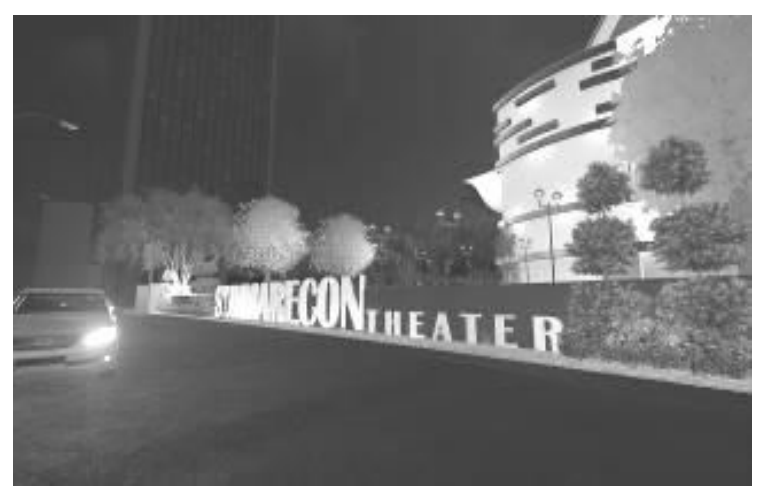

Gambar 14. Muka Site

Sumber: Dokumentasi Pribadi

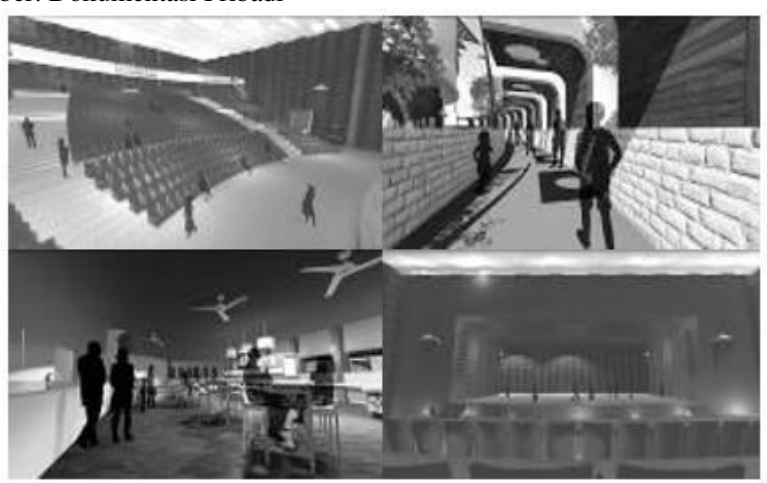

Gambar 15. Entrance dan Ruang Dalam Bangunan

Sumber: Dokumentasi Pribadi

Metafora arsitektural berkenaan dengan pendefinisian wujud bentuk arsitektur (Geoffrey Broadbent), yaitu bagaimana menjelaskan dan mencari hubungan logis antara kiasan tertentu dari arsitek kedalam bentuk ruang bangun rancangannya, sebagai makna kedua disamping pemenuhan fungsi bangunan. Sebagai contoh, bila mengamati sebuah bangunan dengan bentuk-bentuk yang menimbulkan banyak 
kesan, kadang menilainya melalui perbandingan dengan bangunan lain, suatu objek atau konsep yang memiliki kemiripan dan mewakili sifatsifat konsep tersebut. Dengan penilaian seperti itu, jelas bangunan tersebut akan dilihat sebagai kiasan suatu objek atau konsep yang telah diterjemahkan kedalam bentuk bangunan sebagai bentuk ekspresi metaforik.

\section{A. Metoda pada tapak}

Mengadaptasi dari bentukan grand piano yang memiliki bentuk dinamis kemudian ditransformasikan (extrude) keluar pada salah satu sisi bentuk rancangan, sehingga terdapat bentukan baru. Kualitas dari grandpiano mengambil pola string yang bersilangan dan diterapkan untuk eleman tapak luar dari lahan (gambar 6).

\section{B. Metoda pada bentuk atap}

Dengan melihat segalaseuatunya secara abstrak, kualitas akustik dari gedung pertunjukkan, berupa pantulan pantulan yang terjadi dari interior auditoriumnya, sehingga dapat dimanfaatkan sebagai bentuk atap untuk keperluan ciri khas (gambar 7).

\section{HASIL DAN EKSPLORASI}

Objek rancang merupakan objek yang dapat menampung berbagai macam aktivitas masyarakat, khususnya Kota Bekasi yang belum memiliki wadah untuk kegiatan berekspresi dan berapresiasi bagi peminat seni pertunjukan. Arsitektur yang dihadirkan merupakan implementasi dari pendekatan yang dilakukan, mulai dari zoning, sirkulasi, massa bangunan, hingga pada pemaknaan mengenai unsur analogi yang diteraapkan kedalam bangunan.

Arsitektur yang dihadirkan dalam objek rancang "Summarecon Theater: berasal dari bentukan tapak yang mengimitasi bentuk dasar dari grand piano. Dengan pendekatan body language dari unsur seni pertunjukkan dikaitkan dengan suatu hal yang dinamis dimana merupakan segala sesuatu yang selalu bergerak. Sehingga bentukan pada denah yang terbentuk merupakan representasi dari pergerakan yang terus-menerus.

Implementasi Konsep Pada Rancangan adalah sebagai berikut:

\section{A. Zoning}

Objek terdiri dari 5 fasilitas, dengan metode metafora yang tergambarkan dari bentukan dasar tarian (grup) bahwa terdapat posisi melingkar yang artinya society.

Pengelompokkan ini didasari oleh kebutuhan, aksesibilitas, dan privasi dari masing-masing pengguna. Kemudian muncul pengelompokkan fasilitas pengguna, yaitu auditorium, servis area, fasilitas pengelola, fasilitas pengunjung, dan fasilitas ruang luar (gambar 8).

\section{B. Sirkulasi}

Sirkulasi didalam objek dibagi menurut penggunanya yaitu sirkulasi kendaraan, manusia, dan loading. Pola sirkulasi yang digunakan adalah pola sirkulasi radial, yang menempatkan pusat bangunannya yaitu pada auditorium agar pengunjung dapat berjalan dengan nyaman. Untuk sirkulasi didaerah servis memiliki akses pintu masuk dan keluar yang berbeda dari akses keluar masuk yang utama (gambar 9 dan gambar 10).

\section{Massa Bangunan}

Orientasi massa utama lebih tinggi daripada zona fasilitas lainnya. Tampang keseluruhan bangunan utama orientasinya menghadap langsung dari akses jalan.

Peletakan masa objek arsitektural ini akan fokus terhadap bagaimana suatu arsitektur dapat menunjukkan identitas suatu budaya tertentu baik secara langsung maupun tidak langsung (gambar 10)

\section{KESIMPULAN}

Dengan memerhatikan unsur-unsur yang masuk ke dalan seni pertunjukan sehingga dapat mengekspresikan ke arsitekturan terhadap pengguna, bukanlah suatu hal yang tidak mungkin, bila dengan menggunakan pendekatan metafora. Karena arsitektur hadir sebagai perwujudan bahwa dapat menjadi suatu wadah yang dapat tepat sasaran untuk mengedukasi pengguna mengenai pengetahuan serta keterampilan dalam bidang kesenian.

Summarecon Theater dibentuk melalui pendekatan mengenai pemahaman manusia tentang pemikiran abstrak dari sesuatu, yang disini berhubungan dengan seni pertunjukan, sehingga objek ini dapat memberikan peluang-peluang yang berbeda dari setiap individu dan dapat mengetahui maksud awal dari perancangan. Dengan demikian arsitektur dapat terus berkembang dan dapat terus dirasakan kualitasnya oleh penggunanya.

\section{DAFTAR PUSTAKA}

[1] Antoniades, Anthony C. (1990). Poetics of Architecture: Theory of Design. New York: Van Nostrand Reinhold.

[2] Broadbent, Geoffrey, (postscript), (1988). Design in Architecture: Architecture and The Human Sciences. London: David Fulton Publishers.

[3] Lawson, Fred. (2000). Congress. Convention \& Exhibition Facilities: Planning, Design, and Management. Michigan: Architectural

[4] Duerk, Donna P., (1993). Architectural Programming: Information Management for Design. New York: Van Nostrand Reinhold.

[5] Barron, Michael (2009). Auditorium Acoustics and Architectural Design. New York: Spon Press

[6] Kiesler, Frederick. (1964). Inside the Endless House: Art People and Architecture. Jurnal. New York: Simon and Schuster.

[7] Suciyanti, C. 2010. Jurnal Online: "Gestur, Movement, dan Guide" [ONLINE] http://dramakreasi.blogspot.com/2010/04/apa-ya-gesturitu.html\#ixzz4MsuB13nB. Diakses pada tanggal 12 Oktober 2016. 